\title{
Patient Safety in Nursing: A Systematic Review
}

\author{
Mahmood Motamedzadeh ${ }^{1 *}$, Hosein Mahmoudi ${ }^{2, *}$, Batool Nehrir ${ }^{1}$, Abbas Ebadi ${ }^{3}$ \\ ${ }^{1}$ Faculty of Nursing, Baqiyatallah University of Medical Sciences, Tehran, Iran \\ 2 Faculty of Nursing and Trauma Research Center, Baqiyatallah University of Medical Sciences, Tehran, Iran \\ ${ }^{3}$ Behavioral Sciences Research Center, Faculty of Nursing, Baqiyatallah University of Medical Sciences, Tehran, Iran
}

Corresponding Author: Hosein Mahmoudi, Faculty of Nursing and Trauma Research Center, Baqiyatallah University of Medical Sciences, Tehran, Iran. E-mail: h.mahmoudi@bmsu.ac.ir

Received April 24, 2017; Accepted May 14, 2017; Online Published June 29, 2017

\begin{abstract}
Introduction: Patient safety is a major public health problem. In fact, patient safety is a global health concern that affects patients in all areas of healthcare throughout the world, whether in developed or developing countries, and it is important to have a wide range of nursing practices such as education, clinics, and management. Considering the importance of patient safety in the quality of care and outcomes of patients, this study was conducted to systematically review patient safety in Iran and in the world.

Methods: This article follows the review of texts on patient safety dated between 2008 and 2016 found in Internet searches and library studies with the keywords "patient safety training", "quality of care", and "nursing" using databases such as MEDLINE, CINAHL, and ISI, which index the vast majority of published journals and publications. From the articles searched, 23 were obtained and reviewed. Out of the large amount of quantitative and qualitative studies found, articles about the patient safety in nursing were selected and their results are summarized in Table 1 below.

Results: The results of the review of 23 articles showed that patient safety in the majority of Iranian hospitals was at acceptable levels, and only in a few cities such as Shiraz and Hamadan.

Conclusion: According to the review, further planning is needed to improve the patient's safety, such as reducing mistakes, incidents of falling, hospital infections, surgical complications, and improving other safety features so that all hospitals in the future will be upgraded to safety-friendly hospitals.

Keywords: Patient Safety Education; Quality of Care and Nursing

Citation: Motamedzadeh M, Mahmodi H, Nehri B, Ebadi A. Patient safety in nursing: a systematic review. Int J Med Rev. 2017;4(2):52-57. doi: 10.29252/ijmr-040205.
\end{abstract}

\section{Introduction}

Patient safety is a major public health problem. ${ }^{1}$ In fact, patient safety is a global concern in the field of health that affects all areas of healthcare throughout the world, whether in developed or developing countries. It is an important issue in nursing, including the areas of education, clinical education, and management. ${ }^{2}$ Based on the available evidence, it is estimated that between $5 \%$ and $10 \%$ of costs in health systems result from unsafe activities and injuries to patients. In developing countries, one of every ten patients is injured while receiving hospital services. Although there are no accurate statistics about developing countries, the probability is far greater. ${ }^{3}$ Uninsured services, in addition to having unpleasant consequences for the patient and his/her family, lead to stress and an economic burden on the health system and society. ${ }^{4}$ Patient safety includes such concerns as drug errors, surgical procedures, misdiagnoses, device and equipment failures that result in misdiagnoses, and other cases involving hospital infections, patient falls, bed sores, misconduct, etc. ${ }^{5}$ One Harvard study showed that more than $70 \%$ of harmful events for patients were caused by the negligence of healthcare workers, and more than $90 \%$ of them were preventable. ${ }^{6}$ The importance of observing safe nursing practices stems from the pain and suffering that patients and their families suffer from the errors of the treatment team members. The starting point for this suffering is the stress patients feel when paying hospital fees, which increase with prolonged hospitalization. Complications caused not by a patient's initial illness which led them to the healthcare team, but by the mistakes of members of the healthcare team, such as the physician and the nurse, ultimately impose material and emotional costs upon the patient. ${ }^{7}$ Considering the

Copyright (C) 2017 The Author(s). This is an open-access article distributed under the terms of the Creative Commons Attribution License (http://creativecommons.org/licenses/by/4.0), which permits unrestricted use, distribution, and reproduction in any medium, provided the original work is properly cited. 
importance of patient safety in the quality of care and patient outcomes, the current study aimed to systematically review patient safety in Iran and in the world.

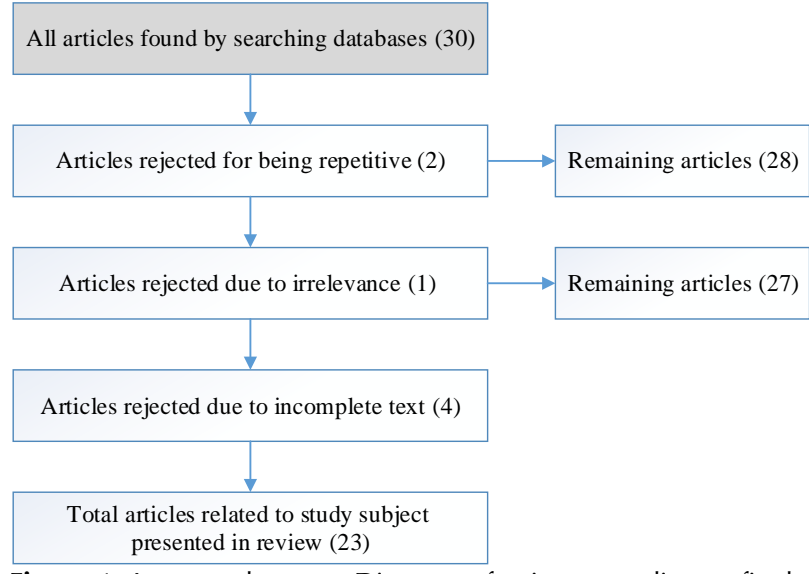

Figure 1: Input and output Diagram of primary studies to final synthesis

\section{Methods}

This article follows the review of texts on patient safety dated between 2008 and 2016 found in Internet searches and library studies with the keywords "patient safety training", "quality of care", and "nursing" using databases such as MEDLINE, CINAHL, and ISI, which index the vast majority of published journals and publications (Figure 1). Out of the large amount of quantitative and qualitative studies found, articles about patient safety in nursing were selected, and their results are summarized in Table 1 below.

\section{Results}

A systematic review of patient safety is summarized in Table 1 (8-30).

Table 1. Information on 23 Patient Safety Articles

Study Results
The total average safety score of patients in hospitals was 63. The dimensions of reporting frequency and data transfer interchange were 56 and 55 , respectively, with the lowest mean and dimensions of "organizational learning" and "expectationsmanagement measures" each with a mean of 69 and the highest average among the 12 dimensions of safety culture.

The two main points of the content analysis were: 1. Creating an educational program on patient safety and turning routine nursing into evidence-based nursing, taking into account patient safety principles. 2 . Involving students in patient care by establishing a link between knowledge and practice and also increasing the correlation between health system providers.

$\% \vee$ of people said employees could not freely question the authorities' actions. $23 \%$ of our work unit's safety culture has a good score and $52 \%$ of the grade. "The scope of team work within units" is one of the strengths of the organization".

The status of all aspects of the patient safety culture is unacceptable (poor) from the viewpoint of nurses in the respective hospitals. The "unit leadership for safety" was the lowest, and "learning and feedback" earned the highest score.

The status of all aspects of the patient safety culture and the two dimensions of the implications of the existence of a safety culture have been low to moderate. The dimensions of "non-punitive reaction to error" and "teamwork between the units of the hospital" had the lowest scores, and "teamwork within the department" had the highest score.

The level of patient safety culture was moderate in different hospitals, and there was no significant difference between hospitals. The strongest dimension of the safety culture, the "work team", achieved $74 \%$ positive response. The organizational posts of people also had a significant difference in the overall score of safety culture.

\begin{tabular}{llllll}
$\begin{array}{l}\text { Society } \\
\text { studied }\end{array}$ & $\begin{array}{l}\text { Sample } \\
\text { size }\end{array}$ & City & Study title & Year & Authors \\
$\begin{array}{l}\text { Medical } \\
\text { personnel }\end{array}$ & 312 & Tehran & $\begin{array}{l}\text { Study of the status of } \\
\text { patient safety culture } \\
\text { from the viewpoint } \\
\text { of staff of teaching } \\
\text { hospitals in Tehran }\end{array}$ & $\begin{array}{l}\text { Mohebifar } \\
\text { et al. }{ }^{8}\end{array}$ & \\
\hline
\end{tabular}

$\begin{array}{lcc}\begin{array}{l}\text { nursing } \\ \text { students }\end{array} & 18 & \text { Iran } \\ & & \\ & & \\ \begin{array}{l}\text { Hospital } \\ \text { staff }\end{array} & 500 & \text { Urmia }\end{array}$

Reviewing the Viewpoints and Suggestions of 201 Weis Nursing Students in Patient Safety for the Development of a Nursing Program in Iran staff

Study of the status of patient safety culture in staff of educational and therapeutic centers affiliated to Urmia University of Medical Sciences

\begin{tabular}{|c|c|c|c|c|c|}
\hline nurses & 215 & $\begin{array}{l}\text { Hama } \\
\text { dan }\end{array}$ & $\begin{array}{l}\text { The Study of the } \\
\text { Dimensions of } \\
\text { Patient Safety Culture } \\
\text { from Hamadan } \\
\text { Nurses' Viewpoints }\end{array}$ & $\begin{array}{l}139 \\
1\end{array}$ & $\begin{array}{l}\text { Shahr } \\
\text { Abadi et } \\
\text { al. }{ }^{11}\end{array}$ \\
\hline $\begin{array}{l}\text { Hospital } \\
\text { staff }\end{array}$ & 313 & Tehran & $\begin{array}{l}\text { Employee perception } \\
\text { of patient safety } \\
\text { culture in selected } \\
\text { hospitals of Tehran } \\
\text { University of Medical } \\
\text { Sciences }\end{array}$ & $\begin{array}{l}139 \\
0\end{array}$ & $\begin{array}{l}\text { Abdi et al. } \\
12\end{array}$ \\
\hline $\begin{array}{l}\text { All health } \\
\text { personnel }\end{array}$ & 443 & Tehran & $\begin{array}{l}\text { Study of the status of } \\
\text { patient safety culture } \\
\text { in teaching hospitals } \\
\text { affiliated to Shahid } \\
\text { Beheshti University } \\
\text { of Medical Sciences } \\
\text { in } 2011\end{array}$ & $\begin{array}{l}139 \\
0\end{array}$ & $\begin{array}{l}\text { Mahfouzp } \\
\text { our et al. }^{13}\end{array}$ \\
\hline
\end{tabular}




\begin{abstract}
Study Results
The strengths of the patient safety culture in university hospitals are three dimensions: "Organizational learning - Continuous improvement", "Teamwork within hospital units", "Non-punitive response in case of mistakes", and in private hospitals are two dimensions: "Organizational learning - Continuous improvement" "And" non-punitive response in the event of an error. "The lowest safety rating in academic hospitals was "Communication and providing feedback on errors," and in private hospitals related to the "transfer of patients to the hospital and the exchange of patient information between units." Most nurses did not report any incidents that occurred during the past year.

The safety rating of the patient was inferior in almost all dimensions to the base hospitals. The two dimensions of "team work within units" and "nonpunitive response in case of error" were identified as the highest and lowest number of the patient safety culture dimensions.

The highest score for the diagnostic sections and paraclinic groups was in the field of "teamwork within the organizational units" $(83 \%)$ and the lowest score for the paraclinic group was in the "non-punitive response to the event of errors" $(42 \%)$. The highest score was part of the special department in the area of "employee issues" (42\%.)
\end{abstract}

About $15 \%$ of patients described the status of the safety culture at a very good level. Among the dimensions of the patient safety culture, the two dimensions of "continuous organizational upgrade" and "teamwork" in the sectors were able to score over $50 \%$.

The patient safety culture is undesirable in all educational hospitals of Shiraz University of Medical Sciences. "Organizational training in patient safety" was the most inadequate dimension, and "how to transfer a patient between sectors" was the most appropriate.

The dimensions of "team work within the sectors" and "overall perception of safety" had the highest scores, and the "non-punitive response to error" had the lowest score among the 12 dimensions of patient safety culture.

"Management support for patient safety" received the highest score, and "non-punitive response in case of error" had the lowest score. People over the age of 35 had a better overall understanding of patient safety.

"Teamwork between hospital units" and "management expectations and management" had the highest scores, and "non-punitive response to error" and "manager support" had the lowest scores. The overall safety culture score was $61.81 \%$.

The condition of the patient safety culture was moderate, and only about $23 \%$ of workers report the status of the patient safety culture as being very good.

The two dimensions of "communication and providing feedback on errors" and "organizational learning and continuous improvement" received the highest scores, and the two dimensions of "non-punitive response in case of errors" and "openness of communication

\begin{tabular}{|c|c|c|c|c|}
\hline $\begin{array}{l}\text { Society } \\
\text { studied }\end{array}$ & $\begin{array}{l}\text { Sample City } \\
\text { size }\end{array}$ & Study title & Year & Authors \\
\hline Nurses & 142 & $\begin{array}{l}\text { Patient safety culture } \\
\text { from nurses' point of }\end{array}$ & $\begin{array}{l}139 \\
0\end{array}$ & $\begin{array}{l}\text { Salavati et } \\
\text { al. }{ }^{14}\end{array}$ \\
\hline
\end{tabular}

view

\begin{tabular}{|c|c|c|c|c|c|}
\hline $\begin{array}{l}\text { Medical } \\
\text { staff }\end{array}$ & 420 & Tehran & $\begin{array}{l}\text { Assessing the status } \\
\text { of patient safety } \\
\text { culture in public } \\
\text { hospitals affiliated to } \\
\text { Tehran University of } \\
\text { Medical Sciences }\end{array}$ & $\begin{array}{l}138 \\
8\end{array}$ & $\begin{array}{l}\text { Maghari et } \\
\text { al. }{ }^{15}\end{array}$ \\
\hline $\begin{array}{l}\text { Medical } \\
\text { staff }\end{array}$ & 332 & Tehran & $\begin{array}{l}\text { Surveying the } \\
\text { Learning Centers of } \\
\text { Patient Safety Culture } \\
\text { at the Educational } \\
\text { Center, Shahid } \\
\text { Rajaee Cardiology } \\
\text { Research Center in } \\
2013\end{array}$ & $\begin{array}{l}139 \\
2\end{array}$ & $\begin{array}{l}\text { Momeni et } \\
\text { al. }{ }^{16}\end{array}$ \\
\hline
\end{tabular}

\begin{tabular}{|c|c|c|c|c|c|}
\hline $\begin{array}{l}\text { Hospital } \\
\text { staff }\end{array}$ & 367 & Jahrom & $\begin{array}{l}\text { Study of the status of } \\
\text { patient safety culture } \\
\text { from the perspective } \\
\text { of medical personnel } \\
\text { in Jahrom University } \\
\text { of Medical Sciences } \\
\text { affiliated hospitals in } \\
2014\end{array}$ & $\begin{array}{l}139 \\
3\end{array}$ & $\begin{array}{l}\text { Zendegani } \\
\text { et al. }{ }^{17}\end{array}$ \\
\hline Nurses & 412 & Shiraz & $\begin{array}{l}\text { Investigating patient } \\
\text { safety culture from } \\
\text { nurses' point of view } \\
\text { in educational } \\
\text { hospitals of Shiraz } \\
\text { and providing } \\
\text { solutions for } \\
\text { improving the status }\end{array}$ & $\begin{array}{l}138 \\
7\end{array}$ & $\begin{array}{l}\text { Hatam et } \\
\text { al. }{ }^{18}\end{array}$ \\
\hline
\end{tabular}

\begin{tabular}{|c|c|c|c|c|c|}
\hline $\begin{array}{l}\text { Medical } \\
\text { staff and } \\
\text { patients }\end{array}$ & 250 & Tehran & $\begin{array}{l}\text { Relationship of } \\
\text { patient safety culture } \\
\text { with patient } \\
\text { perception of service } \\
\text { quality in selected } \\
\text { military hospitals in } \\
2013\end{array}$ & $\begin{array}{l}139 \\
2\end{array}$ & $\begin{array}{l}\text { Zaboli et } \\
\text { al. }{ }^{19}\end{array}$ \\
\hline $\begin{array}{l}\text { Hospital } \\
\text { staff }\end{array}$ & 439 & $\begin{array}{l}\text { Kerma } \\
\mathrm{n}\end{array}$ & $\begin{array}{l}\text { Familiarity of Kerman } \\
\text { Hospital staff with } \\
\text { respect to patient } \\
\text { safety culture }\end{array}$ & $\begin{array}{l}139 \\
3\end{array}$ & $\begin{array}{l}\text { Saber et } \\
\text { al. }{ }^{20}\end{array}$ \\
\hline $\begin{array}{l}\text { Hospital } \\
\text { staff }\end{array}$ & 361 & Yasuj & $\begin{array}{l}\text { Status of patient } \\
\text { safety culture from } \\
\text { the viewpoint of } \\
\text { hospital staff in Yasuj } \\
\text { city in } 2014\end{array}$ & $\begin{array}{l}139 \\
3\end{array}$ & $\begin{array}{l}\text { Rezaian et } \\
\text { al. }{ }^{21}\end{array}$ \\
\hline $\begin{array}{l}\text { Hospital } \\
\text { staff }\end{array}$ & 295 & Jiroft & $\begin{array}{l}\text { Study of the status of } \\
\text { patient safety culture } \\
\text { in hospitals in Jiroft } \\
\text { city in } 2014\end{array}$ & $\begin{array}{l}139 \\
3\end{array}$ & $\begin{array}{l}\text { Faryabi et } \\
\text { al. } 22\end{array}$ \\
\hline $\begin{array}{l}\text { Medical } \\
\text { personnel }\end{array}$ & 164 & Tehran & $\begin{array}{l}\text { Study of the status of } \\
\text { patient safety culture } \\
\text { at Razi Psychiatric } \\
\text { Center, Tehran }\end{array}$ & $\begin{array}{l}139 \\
3\end{array}$ & 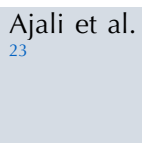 \\
\hline
\end{tabular}


channels" had the lowest scores; half of the units in channels" had the lowest scores; half of the units in
the research did not report any errors in the last year. Hospital ratings in the areas of mandatory, basic, and advanced indicators was $0.76,0.55$, and 0.27 , respectively, among the hospitals under study. Hospitals $C$ and $A$ received the highest and lowest scores, respectively. Hospital B indices (score 0.8), in the basic indices of Hospital $C$ (score 0.66 ) and in the hospital's advanced indices (A score of 0.26 ) earned the highest score. Among the studied areas, "safe environment" $(59.3 \%)$ and "continuing education" $(\mathbf{2 2 . 3} \%)$ had the highest and lowest compliance with the standards, respectively

The three dimensions of "suitability of the status of the cadre", "frequency of reporting of accidents", and "non-punitive policies in the hospital" received the lowest scores, and the three dimensions of "management expectations and patient safety promotion functions", "feedback and exchange of information about errors", and "teamwork inside hospital departments" received twenty points.

The results of the research showed that, from the viewpoint of respondents, the nurses' professional behavior and patient safety culture were in the middle level in the educational centers of Rasht. Moreover, a significant and direct relationship between nurses' professional behavior and patient safety culture was seen $(p<0.01, r=0.6$.
\end{abstract}

"Teamwork within the sectors" got the highest score, and "non-punitive reactions to the error" earned the lowest score. The average overall safety culture of the patient was 89.99.

More than $60 \%$ of the samples did not report any errors. The mean score of the patient's degree of safety in the hospital was 36.3 out of 5 . The dimensions of "management measures and expectations", "teamwork within the units", and "organizational learning" received the highest scores, and the dimensions of "non-punitive response to error" and "sufficient staffing" had the lowest scores.

About $52.7 \%$ of the samples did not report any errors during the past year. Approximately $41 \%$ of the subjects described the patient safety culture as being very good in their hospital. The overall patient safety culture score was $\mathbf{1 . 5 0}$ based on the randomized model. Then "teamwork within the hospital's highest and "non-punitive response to error" scored the lowest.

Among the dimensions of the patient safety culture, the two dimensions of "teamwork within the hospitals" and "organizational learning and ongoing promotion" scored the highest scores, and the two dimensions of "staff" and "non-punitive response to error" had the lowest scores. $53.7 \%$ of nurses reported one to two errors in the past year.

\begin{tabular}{|c|c|c|c|c|c|}
\hline $\begin{array}{l}\text { Society } \\
\text { studied }\end{array}$ & $\begin{array}{l}\text { Sample } \\
\text { size }\end{array}$ & City & Study title & Year & Authors \\
\hline $\begin{array}{l}\text { Owners of } \\
\text { the Patient } \\
\text { Safety } \\
\text { Related } \\
\text { Process }\end{array}$ & 84 & Ahwaz & $\begin{array}{l}\text { Evaluation of Patient } \\
\text { Safety Indicators in } \\
\text { Public Hospitals } \\
\text { Covered by Ahwaz } \\
\text { University of Medical } \\
\text { Sciences Based on } \\
\text { the Patient Safety } \\
\text { Assessment Report of } \\
\text { the World Health } \\
\text { Organization }\end{array}$ & & $\begin{array}{l}\text { Najafpour } \\
\text { et al. }{ }^{24}\end{array}$ \\
\hline nurses & 530 & Amol & $\begin{array}{l}\text { Evaluation of nurses' } \\
\text { point of view on } \\
\text { patient safety culture } \\
\text { in Amol city } \\
\text { hospitals in } 2012\end{array}$ & $\begin{array}{l}139 \\
1\end{array}$ & $\begin{array}{l}\text { Faqih } \\
\text { Zadeh et } \\
\text { al. }{ }^{25}\end{array}$ \\
\hline nurses & 322 & & $\begin{array}{l}\text { The relationship } \\
\text { between patient } \\
\text { safety culture and } \\
\text { nursing professional } \\
\text { behavior within the } \\
\text { framework of the } \\
\text { implementation of } \\
\text { clinical governance }\end{array}$ & $\begin{array}{l}139 \\
2\end{array}$ & $\begin{array}{l}\text { Jabari et } \\
\text { al. }{ }^{26}\end{array}$ \\
\hline $\begin{array}{l}\text { Hospital } \\
\text { staff }\end{array}$ & 280 & & $\begin{array}{l}\text { Patient safety culture } \\
\text { from the point of } \\
\text { view of health care } \\
\text { clinics }\end{array}$ & $\begin{array}{l}139 \\
3\end{array}$ & $\begin{array}{l}\text { Salarvand } \\
\text { et al. }{ }^{27}\end{array}$ \\
\hline $\begin{array}{l}\text { Medical } \\
\text { personnel }\end{array}$ & 196 & & $\begin{array}{l}\text { Assessing patient } \\
\text { safety culture at } \\
\text { Fatemeh Al Zahra } \\
\text { Hospital in } \\
\text { Najafabad }\end{array}$ & $\begin{array}{l}138 \\
9\end{array}$ & ${ }_{28}$ Izadi et al. \\
\hline
\end{tabular}

\begin{tabular}{|c|c|c|c|c|c|}
\hline $\begin{array}{l}\text { Hospital } \\
\text { staff }\end{array}$ & 11 & & $\begin{array}{l}\text { Patient safety culture } \\
\text { in Iranian hospitals: } \\
\text { A systematic review } \\
\text { and meta-analysis }\end{array}$ & & $\begin{array}{l}\text { Saber } \\
\text { Azami et } \\
\text { al. }{ }^{29}\end{array}$ \\
\hline nurses & 456 & $\begin{array}{l}\text { Mazan } \\
\text { daran }\end{array}$ & $\begin{array}{l}\text { Patient safety culture } \\
\text { from the viewpoint } \\
\text { of nurses working in } \\
\text { hospitals in } \\
\text { Mazandaran } \\
\text { province }\end{array}$ & $\begin{array}{l}139 \\
0\end{array}$ & $\begin{array}{l}\text { Sharifi et } \\
\text { al. }{ }^{30}\end{array}$ \\
\hline
\end{tabular}

\section{Discussion}

The systematic review of safety culture surveys in different hospitals in Iran showed that in most hospitals in Iran, patient safety is at an acceptable level. seven studies in the field of safety in Tehran conducted by Mohibi Far and Ashkaran (1391), Abdi et al. (2011), Mahfouzpour et al. (2011), Moghadar et al. (1388), Momeni et al. (1392), Zabali (1392), and Aley et al.
(1393) showed that patient safety in hospitals in Tehran was moderate and acceptable. In two studies in Ahvaz which assessed patient safety indexes with the highest score and continuous education, they earned the lowest score. In a study of safety culture, both in educational hospitals and in private hospitals, "organizational learning" and "non-professorial response to error" 
earned the highest score, while the lowest score in educational hospitals was in communications, and in private hospitals was related to the transfer of patients. This result may be due to the over-crowding in educational hospitals and my health problems in private hospitals are due to the lack of equipment and facilities for the transfer of patients. Two studies in Isfahan showed that the overall viewpoint on patient health and patient safety was acceptable. The study of Shahr Abadi et al. in Hamedan in 2012, however, showed that patient immunity is weak. A study in Urmia also showed that although the patient rating was acceptable, the hospital's atmosphere was not suitable for learning, and the majority of the staff could not comment on the actions of the authorities. In contrast, studies in the northern Iranian cities of Amol, Rasht, and Mazandaran showed that the atmosphere in Amol and Mazandaran had a beneficial effect on teamwork and learning, while the study in Rasht showed that the behavior of the profession the safety of the patient is modest. The study of Faryabi et al. in Jiroft in 2014 indicated that the patient safety culture there is moderate, while patient safety in Shiraz was reported to be undesirable. Studies in other cities of Iran such as Kermanshah, Gonabad, Yasuj, and Khoramabad among others showed that patient safety was acceptable.

\section{References}

1. Lenburg CB, Abdur-Rahman VZ, Spencer TS, Boyer SA, Klein CJ. Implementing the COPA model in nursing education and practice settings: promoting competence, quality care, and patient safety. Nurs Educ Perspect. 2011;32(5):290-6. pmid: 22029239.

2. Rashvand F, Ebadi A. Designing and validation of safe nursing care assessment tool: A sequential exploratory mixed -methods design. Tehran Tehran Medical University; 2014.

3. Johnstone MJ, Kanitsaki O. Culture, language, and patient safety: Making the link. Int J Qual Health Care. 2006;18(5):383-8. doi: 10.1093/intqhc/mzl039. pmid: 16956931.

4. Fleming $M$, Wentzell N. Patient safety culture improvement tool: development and guidelines for use. Healthc Q. 2008;11(3 Spec No.):10-5. pmid: 18382154.

5. Vincent C. Patient safety: John Wiley \& Sons; 2011.

6. Hosseini F, Kazemi M, Akbari A. [he Role of General health, in the Occurrence of Nursing Errors among Nurses in Rafsanjan University of Medical Sciences in 2012]. Rafsanjan Univ Med Sci J. 2014;7(4):27-35.

7. Vaismoradi M, Salsali M, Turunen H, Bondas T. Patients' understandings and feelings of safety during hospitalization in Iran: a qualitative study. Nurs Health Sci. 2011;13(4):40411. doi: 10.1111/j.1442-2018.2011.00632.x. pmid: 21883768.

8. Mohebi Far R, Safari Variani A, Khoshtarkib H, Ghanati E, Teymouri F, Zakaria Kiaei M, et al. [Studying patient safety culture from the viewpoint of staffs in educational hospitals in Tehran City]. Health Saf Work. 2015;5(1):57-64.

9. Vaismoradi $M$, Bondas $T$, Jasper $M$, Turunen $H$. Nursing students' perspectives and suggestions on patient safety-implications for developing the nursing education

\section{Conclusion}

Although studies in various hospitals in Iranian cities showed that patient safety was moderate or good in the majority of hospitals, there remains a need for more planning to improve patient safety in areas such as reducing mistakes, patient falls, hospital infections, surgical complications, and other safety issues in the future so that all hospitals are promoted to hospitals that are safe for the patients.

\section{Ethical Approval}

The current study was approved by the Ethics Committee of a local hospital.

\section{Authors' Contributions}

All authors contributed equally to this study.

\section{Conflict of Interest Disclosures}

The authors declare that they have no conflicts of interest.

\section{Funding}

This study received a grant from the Clinical Research Development Unit of Baqiyatallah hospital.

\section{Acknowledgments}

The Authors would like to thank from the "Clinical Research Development Unit" of Baqiyatallah Hospital for their kindly cooperation.

curriculum in Iran. Nurse Educ Today. 2014;34(2):265-70. doi: 10.1016/j.nedt.2012.10.002. pmid: 23116928.

10. Baghaei R, Nourani D, Khalkhali H, Pirnejad H. [Evaluating Patient Safety Culture in Personnel of Academic Hospitals in Urmia University of Medical Sciences in 2011]. J Urmia Nurs Midwifery Fac. 2012;10(2).

11. Shahrabadi R, Moeini B, Roshanai G, Dashti S, Kafami V, Haghighi M. [Assessing Hamadans Nurses Perceptions of Patient Safety Cultures Dimensions]. J Hosp. 2014;12(4):8390.

12. Abdi ], Maleki M, Khosravi A. [Employee perception of patient safety culture in selected hospitals of Tehran University of Medical Sciences]. Monitoring. 2009;10(4):411-9.

13. Mahfoozpour S, Ainy E, Mobasheri F, Faramarzi A. [Patients' safety culture status among educational hospitals of Shahid Beheshti University of Medical Sciences in 2011]. Pajoohandeh J. 2012;17(3):134-41.

14. Salavati S, Fanoosi T, Dehghan D, Tabesh H. [Nurses' perspectives on patient safety culture]. Iran J Nurs. 2013;26(84):24-33.

15. Moghri J, Akbari Sari A, Rahimi Forooshani A, Arab M. [Patient safety culture status in general hospitals affiliated to Tehran University of Medical Sciences]. Hakim Health Sys Res. 2013;16(3):243-50.

16. Momeni B, Golpira R, Mayelafshar M. [The study of the domains of patient safety culture in Rajaie Cardiovascular, Medical and Research Center in 2012]. Iranian J Cardiovasc Nurs. 2014;3(1):34-41.

17. Zendegani N, Zarezadeh N, Montasari M, Rabiei S. [Evaluating patient's safety from the perspective of healthcare officials in hospitals affiliated with jahrom University of 
Medical Sciences in 2014]. J Educ Ethics Nurs. 2015;3(4):4957.

18. Hatam N. Investigating patient safety culture from nurses' point of view in educational hospitals of Shiraz and providing solutions for improving the status. Shiraz: Shiraz university of medical sciences.

19. Zaboli R, Hasani M, Khalagi K, Bahadori M, Shirzad H. [The Relationship between Patient Safety Culture and Patients' Perception of Healthcare Quality in Military Hospitals in 2013]. Q Mil Med. 2014;1(3):19-30.

20. Saber M, Tehrani H, Kabootarkhani MH, Sabagh MG, Bagheri M. [Acquaintance of Kerman Hospitals' Staff about Patient Safety Culture]. J Health Dev. 2015;4(2):124-32.

21. Rezaean M, Aqaie Borz Abad P, Yazdanpanah A, Zinat Motlagh S. [Patient Safety Culture Status From The Perspective Medical Staff Of Yasuj Hospitals In 2015]. Armaghan-e-danesh. 2016;20(10):935-46.

22. Faryabi R, Shahbazi $H$, Alizadeh Siuki H, Rahimi T. The Investigation of the patient safety culture status in Hospitals of Jiroft City in 2014. J Torbat Heydariyeh Univ Med Sci. 2015;2(4):23-30.

23. Ajalli A, Khoshknab M, Dibaee $M$. The survey of patient safety culture in razi psychiatric center in Tehran. Health Promot Manage. 2015;4:85-94.
24. Najafpour J, Boroumand S, Zahiri M. Evaluation of Patient Safety Indicators in Public Hospitals Covered by Ahwaz University of Medical Sciences Based on the Patient Safety Assessment Protocol of the World Health Organization. Ahwaz Univ Med Sci J. 2012;5(1):47-58.

25. Faghizadeh S, Asoori M. Assessment of Nurses Viewpoints on Patient Safety Culture in Amol Hospitals in Iran, 2012. Prev Care Nurs Midwifery J. 2015;4(2):45-55.

26. Jabari F, Ooshaksaraie M, Azadehdel M, Mehrabian F. Relationship between patient safety culture and professional conduct of nurses in context of clinical governance implementation. J Holist Nurs Midwifery. 2015;25(3):27-33.

27. Salarwand S, Moayed Kazemi A, Bahri N, Dalvand P, Moghimiyan M. Patient safety culture from the perspective of medical staff Assessing medical staff's view of patient safety culture. Q J Nurs Manage. 2013;4(3):54-64.

28. Izadi A, Derrickand J, Abraz A. [Assessing patient safety culture at Fatemeh Al-Zahra Hospital in Najafabad]. Sci Res. 2010.

29. Azami-Aghdash S, Azar FE, Rezapour A, Azami A, Rasi V, Klvany K. [Patient safety culture in hospitals of Iran: a systematic review and meta-analysis]. Med J Islamic Republic Iran. 2015;29:251.

30. Sharifi S, Izadi-Tame A, Hatamipour K, Sadeghigooghary N, Safabakhsh L. [Patient safety culture from Mazandaran clinical nurses' perspective]. Iran J Nurs. 2014;27(88):77-87. 